原 著

\title{
視床ペニシリンてんかんモデルに抢ける焦点成熟過程と 伝播様式に関する検討
}

その 2. 短潜時体性感覚誘発電位 (SSEP) と皮質誘発反応 (CR) に及ぼす影響

\section{Experimental Studies on Development and Propagation of Epileptic Spikes in Penicillin-induced Thalamic Focus Model \\ Part 2. Effects on Somatosensory Evoked Potentials and Cortical Response}

\author{
曽 我 哲 朗*
}

\begin{abstract}
要旨：猫の視床後外腹側核 (VPL) 飞 Pc 焦点を作成し，正中神経刺激による短潜時体性 感覚誘発電位 (SSEP) とVPL 刺激による皮質誘発反応 (CR) に及洔す影響に関して検 討した。第一体性感覚野 (SI) 記録での $\operatorname{SSEP}$ は，陽性波 $\left(\mathrm{P}_{1}\right)$ と陰性波 $\left(\mathrm{N}_{1}\right)$ から成 り，ictal stage 飞执いて両側 SI 記録とも大脳皮質由来と考兄られる $\mathrm{N}_{1}$ の正常波形は 消失していたが，視床由来と考苀られる $\mathrm{P}_{1}$ の前半部は残存していた。このことから ictal stage においても正中神経刺激によるインパルスが視床 VPL ニューロンにまで到達して いたのではないかと推察された。 $\mathrm{SI} て ゙$ 記録した $\mathrm{CR}$ は， $\mathrm{n}_{1}, \mathrm{n}_{2}, \mathrm{n}_{3}$ の 3 陰性波から成 り，ictal stage に执いて $\mathrm{n}_{3}$ が消失または逆転する傾向を示していたのに対し， $\mathrm{n}_{1}, \mathrm{n}_{2}$ は明らかに認められて抢り，VPL 刺激によるインパルスが大脳皮質深層にまで到達して いたことを示しているのではないかと考学られた。
\end{abstract}

てんかん研究 1989； 7：179-188

Key Words : epilepsy, penicillin, thalamus, somatosensory evoked potentials, cortical response.

（受付 : 1989年 2 月 21 日, 訂正 : 1989年 7 月 11 日, 受理 : 1989年 7 月 13 日)

はじめに

近年, 皮質てんかん焦点と各種誘発電位との相 関に関する報告が増加しつつあり，動物実験では

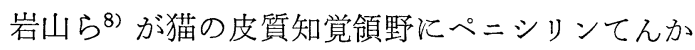
几焦点を作成して体性感覚誘発電位 (somatosensory evoked potentials: SEP) の変化を検討し, 発作波検知と同時に坐骨神経を刺激してもSEP と思われる成分は全くみられなかったとしてい
る。高橋 ${ }^{13}$ は rat の皮質知覚領野に Pc 焦点を 作成し, 棘波が頻発している時期では SEP 成分 の振幅の縮小傾向と各成分の潜時延長を認めてい る。これらの報告に対して鶴ら ${ }^{14)}$ は，猫の扁桃核 刺激による Kindling を用いて聴覚誘発電位の変 化を検討し，Kindling の成立に伴い聴覚誘発電 位の振幅の増大と短縮をきたしたと報告してい る。Mirsky ら ${ }^{11)}$ はサルの皮質焦点モデルに抒い て視覚誘発電位を検討し, 棘徐波結合発現時には

* 徳島大学医学部脳神経外科

[干770 德島市蔵本町 3-18-50]

Tetsuro Soga

Department of Neurological Surgery, School of Medicine, The University of Tokushima 
誘発電位が減弱あるいは消失するとしているが， これに反して Burchliel ら²は猫を用いたPc んかんモデルに扣いて視覚誘発電位の増大を観察 している。このように, 焦点部位や誘発電位の違 いにより異なった結果が生じて和り，一定した見 解が得られていないのが現状である。

そこでここでは, 前編（その1）に和いて報告 した視床後外腹側核 (ventral posterolateral nucleus；VPL）ペニシリンてんかんモデルを用い て SEP と皮質誘発反応 (cortical response: CR) に及ぼす影響に関して検討したので，その結果を 報告する。

\section{実 験方法}

\section{1. 対象および手術方法}

前編化いてて作成した視床ペニシリンてんかん モデル猫（2.5〜4. $5 \mathrm{~kg}$ ）を使用した。実験方法 の詳細は前編に譲るが，広範囲開頭時の麻酔には Ketamine chlorate $(10 \mathrm{mg} / \mathrm{kg})$ を用いた。カニ ニーラ付き双極電極（電極間距離 $3 \mathrm{~mm}$ ) を定位 的に両側 VPL に刺入乙た段階で脳波, SEP お。 よび CR を記録し control studyを行った。ま た電極設置後は, 体動が激しくない限り, Ketamine chlorate 追加せず，無麻酔に近い状態 で実験を続行した。次に $10 \mu l$ の Pc 溶液 (1× $\left.10^{6} \mathrm{U} / \mathrm{m} l\right)$ をマイクロシリンジを用いて左 VPL に注入乙連続脳波記録にて視床 Pc 焦点成熟過 程, stage I (散発棘波期), stage II (頻 発棘波 期)， stage III（発作発射期）を観察した。

\section{SEP 記録}

日本三栄製電気刺激装置 $7 \mathrm{~F} 46$ を用いて一側 手関節部正中神経を電極問距離 $1 \mathrm{~cm}$ で矩形波に より刺激した（持続時間 $100 \mu \mathrm{s}$, 頻度 $10 \mathrm{~Hz}$ )。 刺激強度は, 運動閾值の 3 倍とした（電圧10１5 V)。SEP 記録は, 日本電気三栄製 Signal processor $7 \mathrm{~T} 17$ (周波数带域 $30 \sim 3,000 \mathrm{~Hz}, 200$ 回 加算平均）を用いた。分析時間は $20 \mathrm{msec} と し$ て短潜時体性感覚誘発電位 (short latency somatosensory evoked potentials: SSEP) を記録し た。記録部位は対側 VPL, 第一体性感覚野 (SI), 第一運動野(MI) の 3 箇所とした。Control study に拈ける VPL での記録は, カニューラ付き双極
電極が VPL に到達する数 $\mathrm{mm}$ 手前から $1 \mathrm{~mm}$ 毎 に記録しつつ, VPL に持ける典型的な SSEP 波 形が得られるまで電極を刺入した後, 実験終了ま でこの位置で電極を固定した。

\section{3. $\mathbf{C R}$ 記録}

$\mathrm{CR}$ 記録は SSEP 記録と同様に 電気刺激装置 を用いて一側 VPLを矩形波により刺激した (持続時間 $100 \mu \mathrm{s}$, 電圧 $3 \mathrm{~V}$, 頻度 $10 \mathrm{~Hz}$ )。 CR 記録は, Signal processor $7 \mathrm{~T} 17$ (周波数帯域 30 $\sim 3,000 \mathrm{~Hz}$ ，分析時間 $20 \mathrm{msec}, 100$ 回加算平均） を用いて同側の SI と MI とて記録した。

視床 Pc 焦点成熟過程の各 stage での SSEP および CR 記録は20匹の猫に扣いて行い，それ ぞれの変化に関して検討した。

\section{結果}

\section{Control study における SSEP および CR}

\section{(1) SI の部位決定}

$\mathrm{MI}, \mathrm{SI}$ の周辺に $5 \mathrm{~mm}$ 間隔で計20箅所に電極 を配置し SSEPを同時記録し，陰性成分の最も 高振幅な波形が得られたところをSI とした(Fig. $1 \mathrm{a})$ 。同様にして VPL 刺激による CR を同時 記録するとSSEP で陰性成分の高振幅の波形が 得られたところに一致して陰性成分の高振幅な $\mathrm{CR}$ が得られ，SI の正確な位置が決定できた (Fig. 1b)。また MI で記録した波形は，SI で の最も高振幅な陰性成分に対して位相の逆転傾向 が見られた (Fig. 2)。

\section{(2) SSEP と GR の基本波形}

VPL で記録した典型的な SSEP は，潜時 5.0 $\pm 0.5 \mathrm{msec}$, 最大頂点潜時 $7.1 \pm 0.6 \mathrm{msec}(\mathrm{n}=$ 18）の多峰性陽性波であり（Fig. 3 a), VPL に 近づくにつれ陽性成分がその振幅を増し，VPL 通過後は速やかに陰性成分への逆転を示してい た (Fig. 3 b)。SI で記録した SSEP は，小さな peak を伴う陽性波 $\left(\mathrm{P}_{1}\right)$ と大きな振幅を持つ陰 性波 $\left(\mathrm{N}_{1}\right)$ によって構成されて扣り， $\mathrm{P}_{1}$ 潜時が 9. $4 \pm 0.9 \mathrm{msec} ， \mathrm{~N}_{1}$ 潜時が $14.1 \pm 0.8 \mathrm{msec}(\mathrm{n}=$ 20)であった。SI で記録した CR は，連続した 小さな陰性波 $\left(\mathrm{n}_{1}, \mathrm{n}_{2}\right)$ と高振幅の陰性波 $\left(\mathrm{n}_{3}\right)$ から成り，それぞれの潜時は $1.3 \pm 0.4 \mathrm{msec}$, 3. $2 \pm 0.4 \mathrm{msec}, 6.8 \pm 0.8 \mathrm{msec}(\mathrm{n}=20)$ であっ 

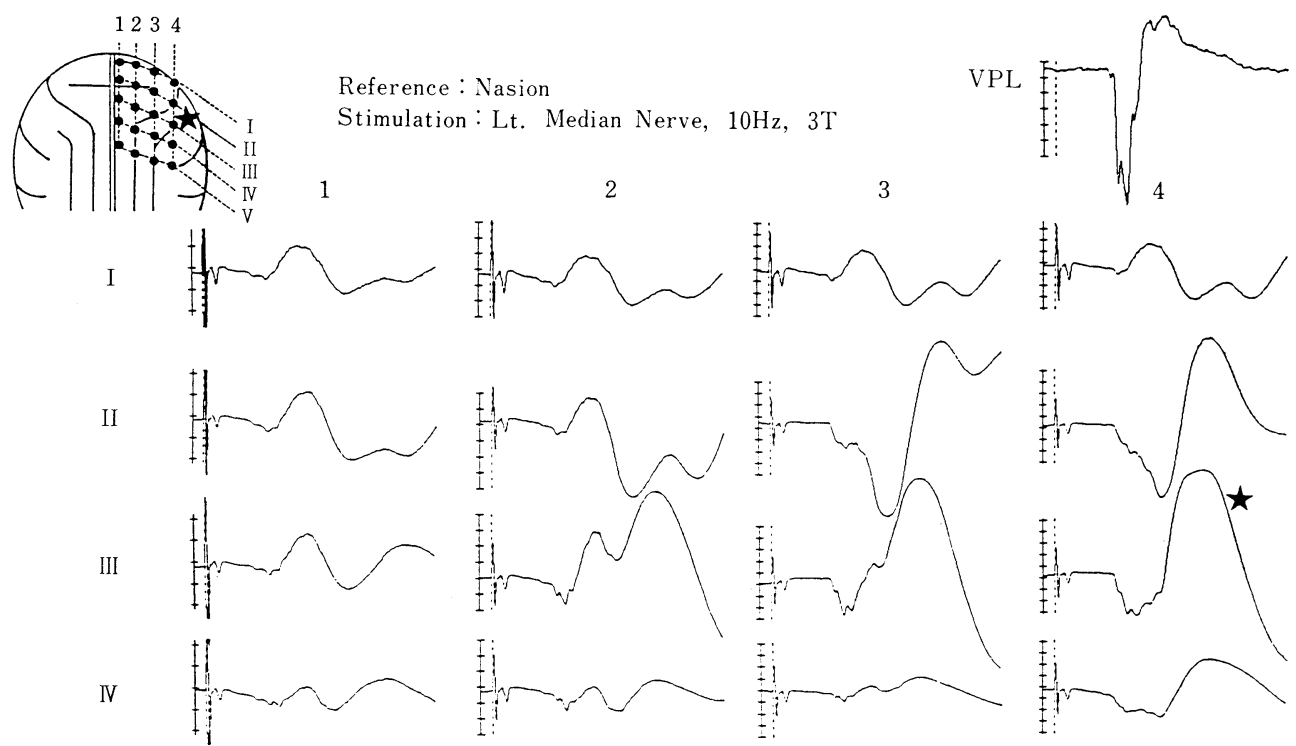

IV
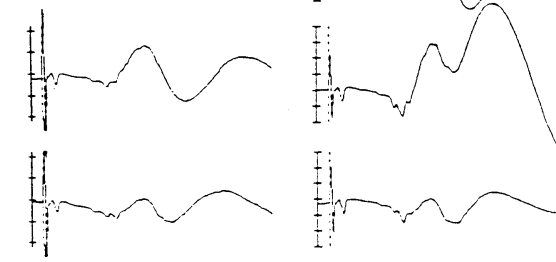

$\mathrm{V}$
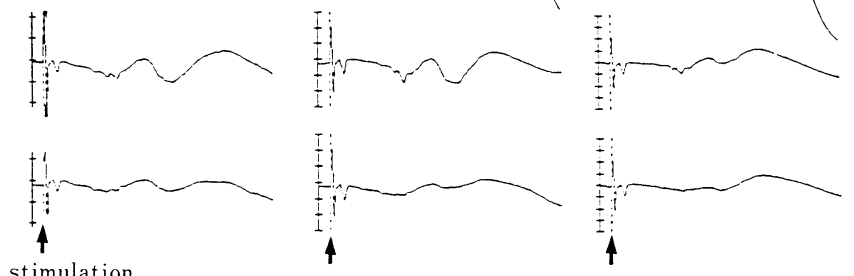

a

stimulation

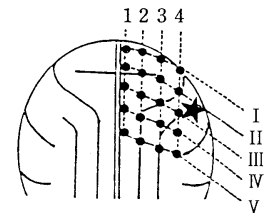

Reference: Nasion

Stimulation: Rt. VPL, $10 \mathrm{~Hz}, 3 \mathrm{~V}$
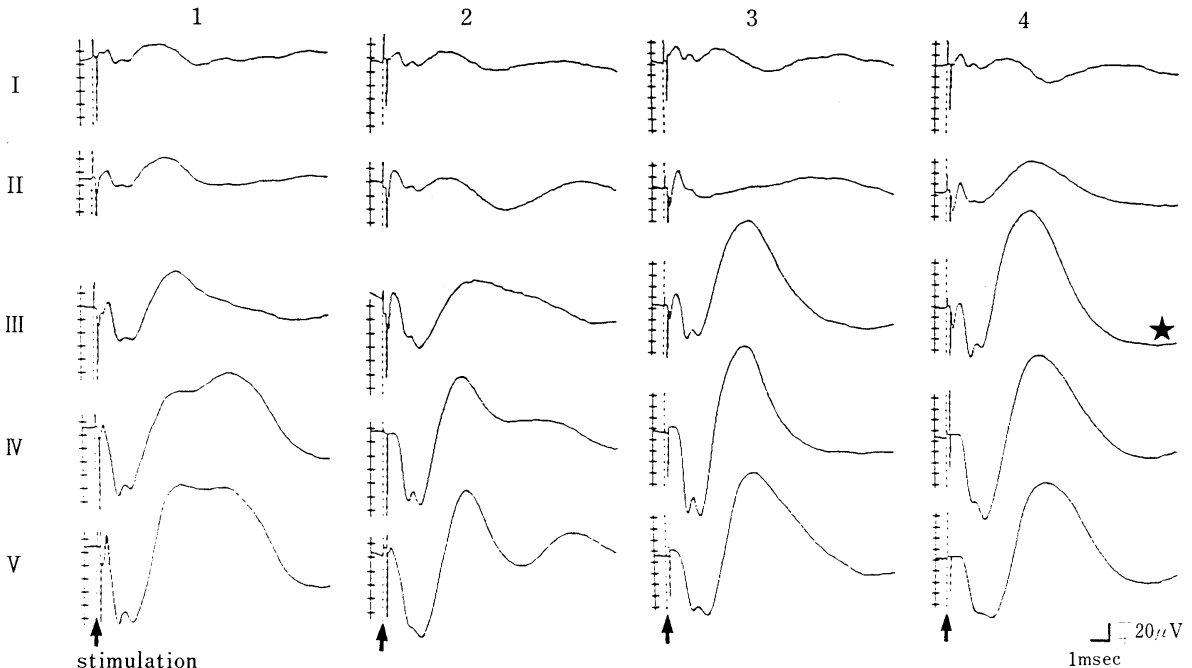

b
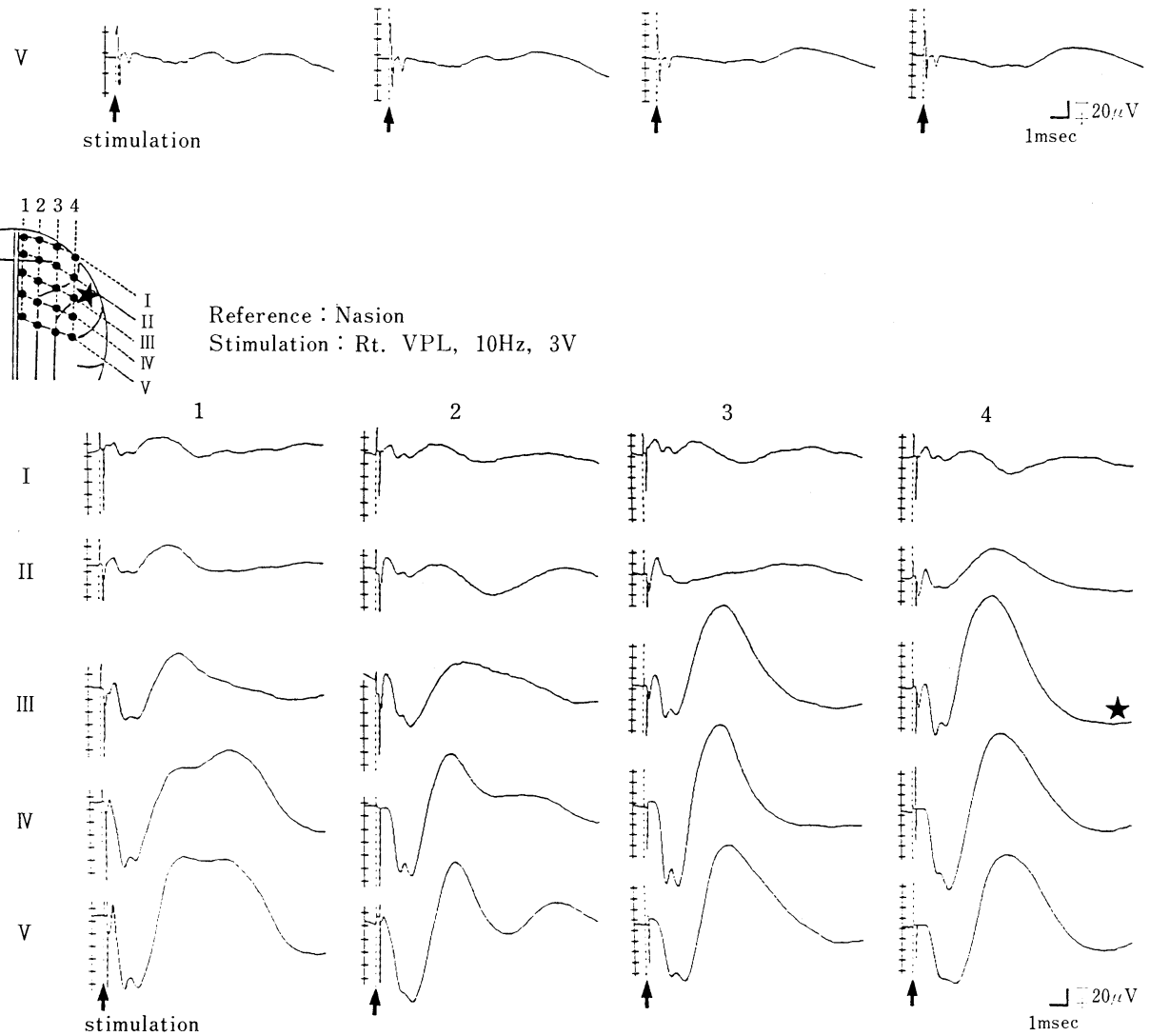

Fig. 1 Topographycal analysis of short latency somatosensory evoked potentials (SSEP) and cortical response (CR)

The star indicates the primary somatosensory area obtained the best recording of SSEP (Fig. $1 \mathrm{a}$ ) and CR (Fig. $1 \mathrm{~b}$ ) recorded from the cortical surface. 


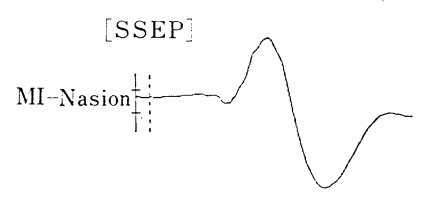

$[\mathrm{CR}]$
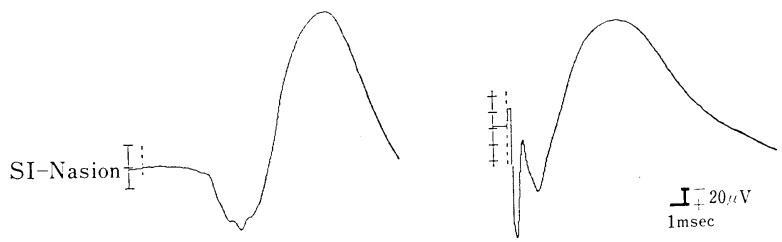

Fig. 2 Comparison with components of SSEP and CR recorded from the primary motor area $(\mathrm{MI})$ and primary somatosensory area (SI)

Each components showing a phase-reversal between MI and SI.

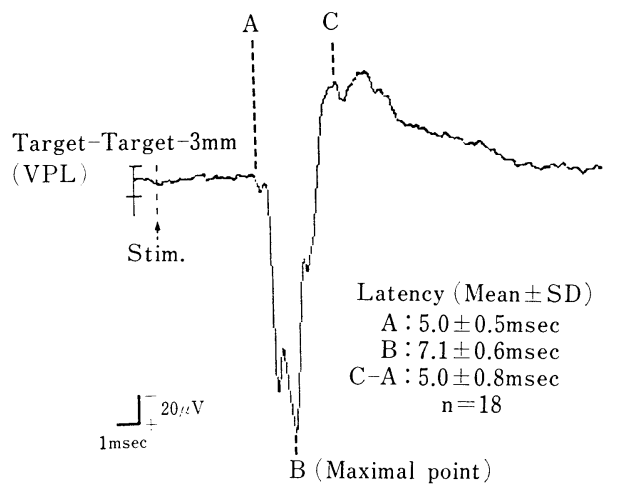

Fig. 3 a

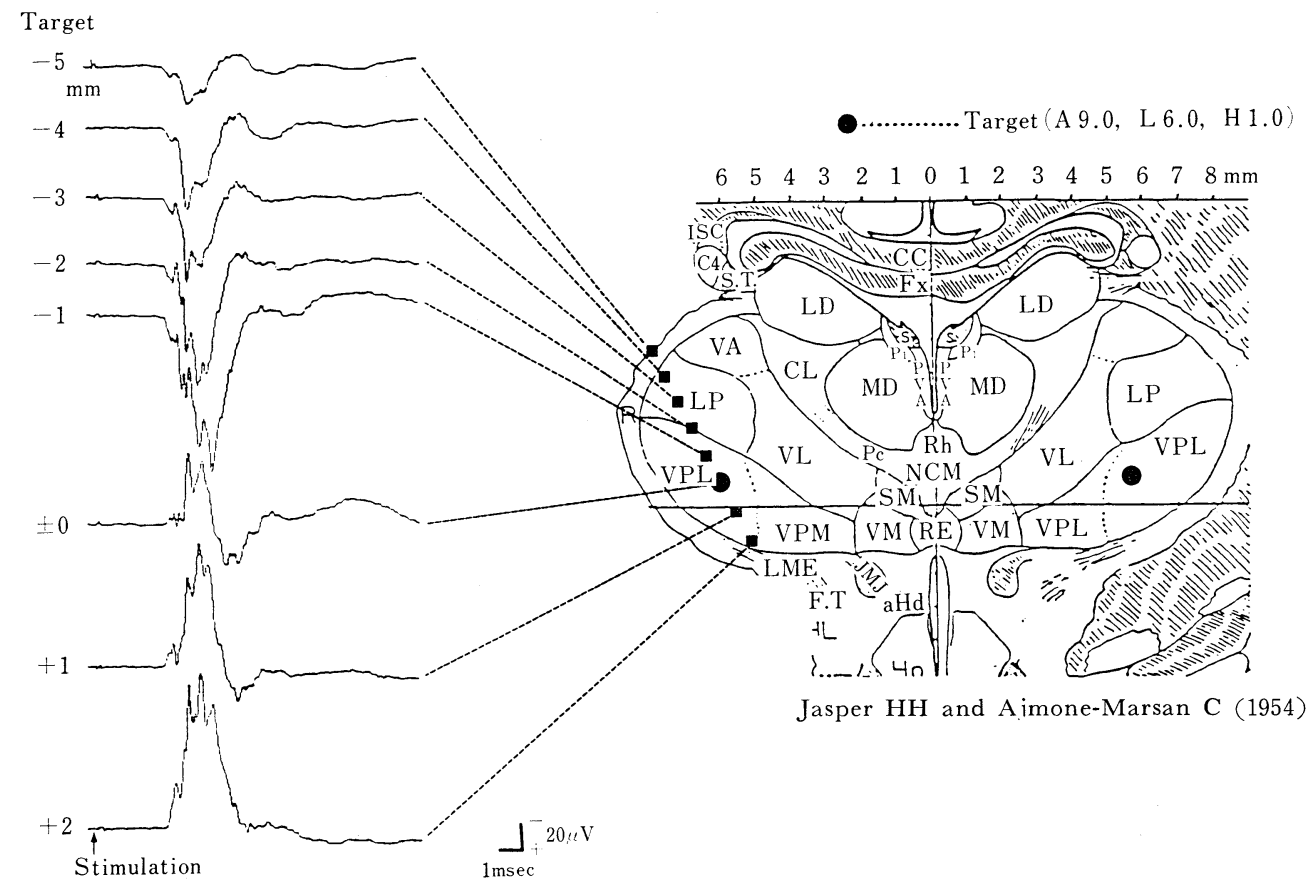

Fig. 3 SSEP recorded from the ventral posterolateral nucleus (VPL) elicited by the median nerve stimulation

The mean latency and standard deviation of each point area shown in the right part of Fig. 3 a. Serial recordings of SSEP from the thalamus show that positive deflections are reversed to negative at VPL (Fig. $3 \mathrm{~b}$ ). Zero is set in VPL (circle) and depth in $\mathrm{mm}$ at which records were made are given at left of each trace and correspond to those in the right atlas of Fig. $3 \mathrm{~b}$. 
SSEP (Stimulation : Median Nerve)

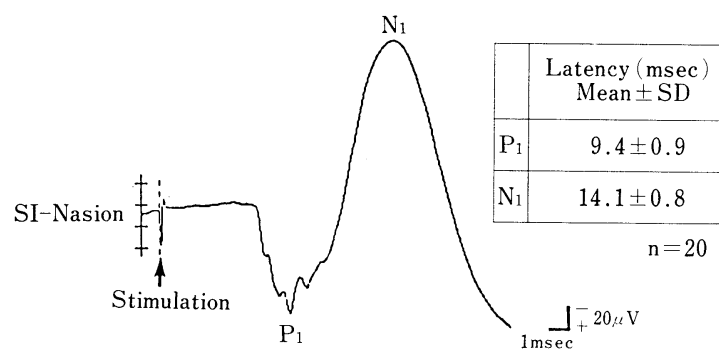

CR (Stimulation : VPL)

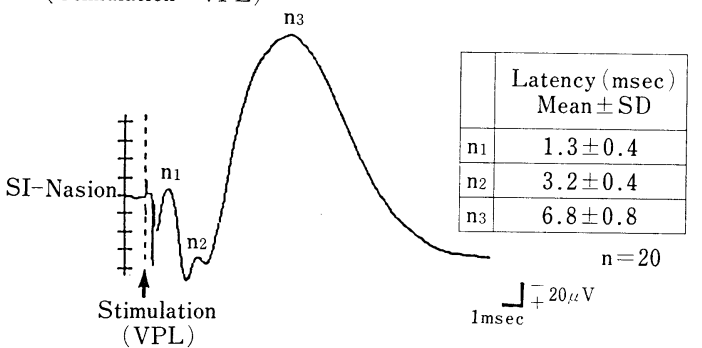

Fig. 4 Tipical SSEP and CR recorded from SI SSEP recorded from SI consists of $P_{1}$ and $\mathrm{N}_{1}$. CR consists of two small negative waves $\left(n_{1}, n_{2}\right)$ followed by a large negative wave $\left(n_{3}\right)$. The mean latency and standard deviation of each component are shown in the right part of Fig. 4.

た (Fig. 4)。また 5 匹には， control study とし てカニューラ付き双極電極の先端電極を用い単極 誘導で記録した SI での SSEP と CR の皮質層 分析を行った。この両者を比較すると皮質深層に 行くに従い $\mathrm{N}_{1}$ と $\mathrm{n}_{3}$ の振幅がともに減少し, 逆 転していく傾向を認めた（Fig. 5)。

\section{2. 視床 Pc 焦点成熟過程における SSEP およ び GR の変化}

\section{(1) Pc 注入側での変化}

脳波上 Pc 注入側 VPL に散発的な棘波の出現 をみる stage I, 頻発する棘波や時に後発射を認 わる stage II に括いて SI で記録した SSEP は, ほとんど変化を認めないかあるいは軽度の振幅低 下を示すのみであった (Fig. 6 a)。VPL で記録 した SSEP や SI で記録した CR も同様の傾向 を認めた (Fig. 6a，6b)。これに対して Pc 焦 点が充分成熟したと考它られる stage III に打いて

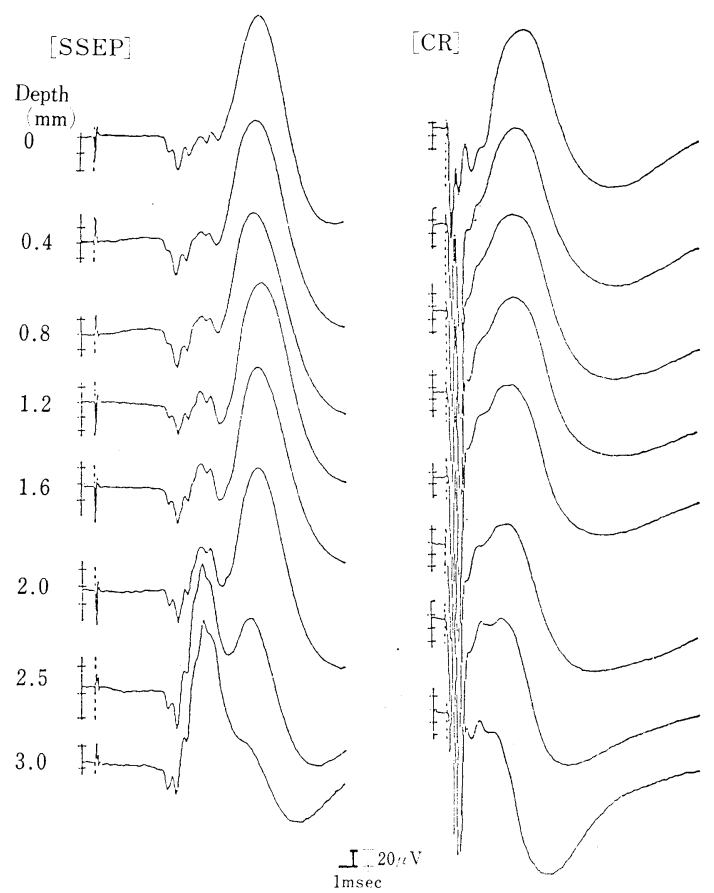

Fig. 5 Laminography of SSEP and CR recorded from SI

$\mathrm{N}_{1}$ of SSEP and $\mathrm{n}_{3}$ of $\mathrm{CR}$ are not clear in the lowest leads recorded at depth $3 \mathrm{~mm}$ from the cortical surface.

ictal discharge が全誘導に認められる時期 (ictal stage) 飞 SSEPをSIで記録すると正常波形を 示さず， $\mathrm{P}_{1}$ 潜時は延長し $\mathrm{N}_{1}$ は確認でさなかっ た (Fig. 6 a)。SI で記録した CR でも $\mathrm{n}_{3}$ の正 常波形は消失し時に逆転する傾向を認めたが， $\mathrm{n}_{1}, \mathrm{n}_{2}$ にはほほんど変化を認めなかった (Fig. 6 a)。また interictal stage では, SI で記録した SSEP, CR ともに stage II に护友形に復して いた (Fig. 6a)。Ictal stage に括いて VPL で 記録した SSEPをみると振幅の低下と持続時間 の延長を認めたが，波形が消失するには至らなか った (Fig. 6 b)。

\section{(2) Pc 非注入側での変化}

各 stage 飞执将るSSEP は, SI での記録, VPL での記録ともにPc 注入側での变化と類似 していた。特に stage $\mathbb{I}$ の ictal stage に和ける SI での記録をみると, Pc 非注入側に括いても正 


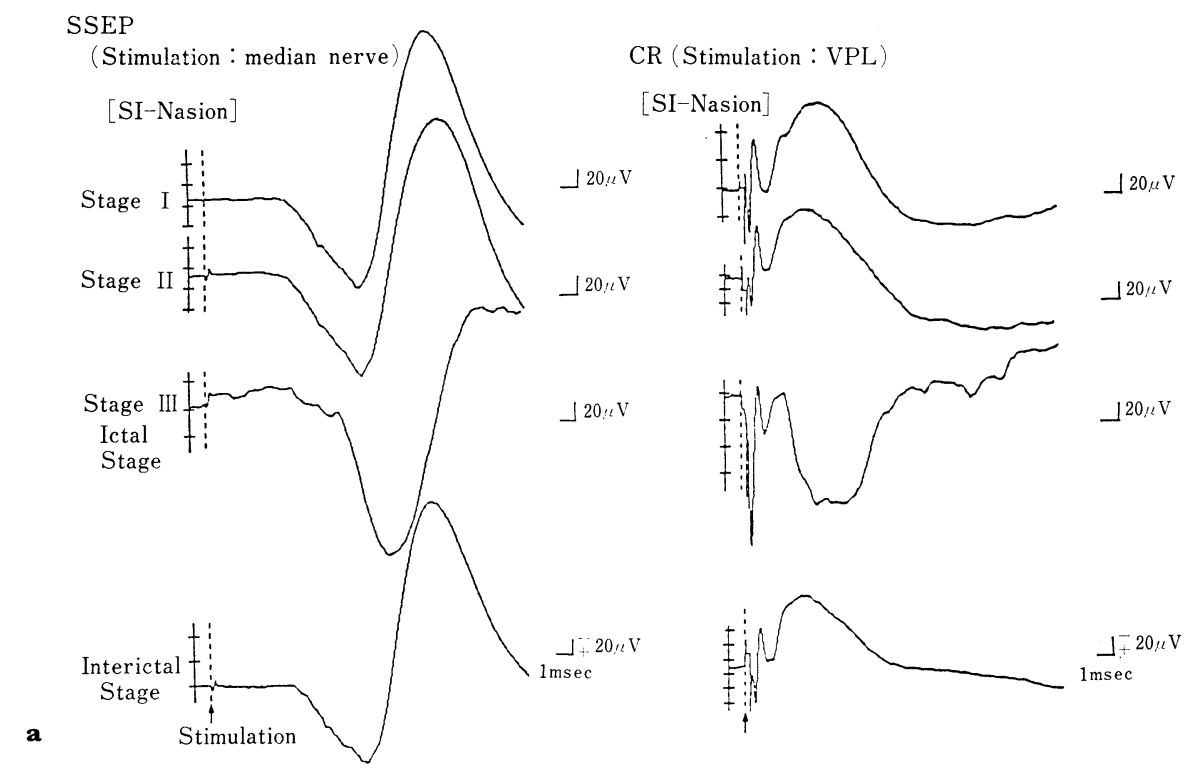

[SI]

$[\mathrm{VPL}]$

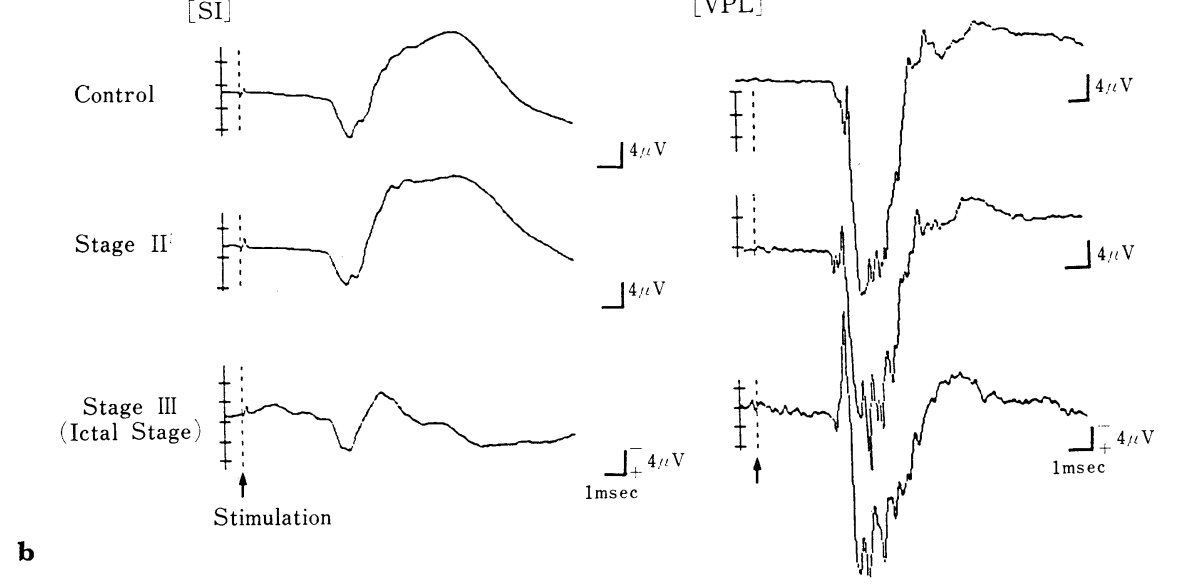

Fig. 6 Changes in SSEP and CR recorded from Pc injection side during the development of thalamic focus from stage I to $\mathbb{I I}$

The latency of $P_{1}$ prolongs and $N_{1}$ disappears at ictal stage of stage $\mathbb{I}$. The latencies and amplitudes of $n_{1}$ and $n_{2}$ reveal no remarkable changes but $n_{3}$ is reversed to positive at ictal stage of stage $\mathbb{I I}$. In interictal stage, SSEP and CR return normal patterns (Fig. $6 \mathrm{a}$ ). The amplitude of positive wave of SSEP recorded from VPL decreases but not disappear at ictal stage Fig. $6 \mathrm{~b}$ ).

常波形の消失が観察された（Fig. 7 a)。SI で記 録した CR では, interictal stage に拈いてもほ ぼ正常波形が保たれていたが， ictal stage では $\mathrm{Pc}$ 注入側と同様に $\mathrm{n}_{3}$ の消失または逆転傾向が 見られた (Fig. 7 b)。

\section{考察}

\section{SI で記録した SSEP 並びに GR における} 構成成分の起源に関して

Brooks ら ${ }^{1)}$ にると, 猫の SEP にみられる最 

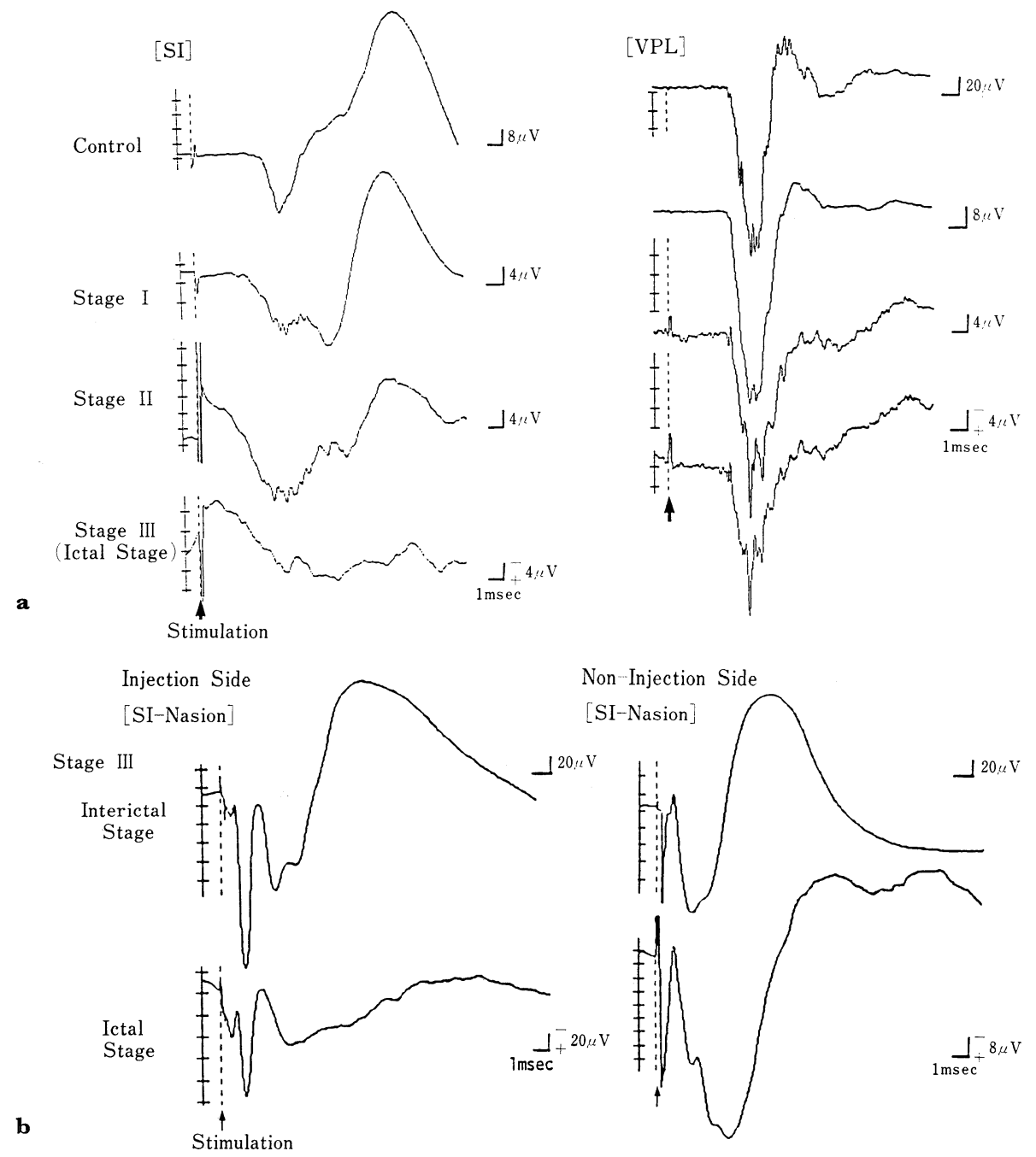

Fig. 7 Changes in SSEP and CR recorded from Pc non-injection side during the development of thalamic focus from stage $I$ to $I I$

Changes of SSEP from Pc non-injection side (Fig. 7 a) are the same as that from Pc injection side. Changes of $\mathrm{CR}$ in stage $\mathbb{I I}$ are obtained by both recordings of Pc injection and non-injection sides, similarly (Fig. $7 \mathrm{~b}$ ).

初の陽性成分は, 皮質 $\mathbb{I I}, \mathrm{IV}$ 層に生じた興奮性シ ナプス後電位起源であり，これに続く陰性成分 は，皮質深層の大錐体細胞の尖端樹状突起自体の 興奮, もしくは, そのシナプス後電位起源である としている。Iragui-Madoz らっは猫 SEP におい て component I から $\mathbb{V}$ までの far field potentials を記録して扣り，これらの起源として component I は頸髄, II は楔状核あるいは内側毛帯, IIIは小 脳経路扣よび視床 VP 核, IVは視床から皮質感
覚領野間が考兄られると述べている。最近では, Dong ら ${ }^{5)}$ の報告にあるように $\mathrm{P}_{1}$ に相当する成分 が視床あるいは thalamocortical projection 由来 であり， $\mathrm{N}_{1}$ に相当する成分が皮質感覚領野由来 であるらと考光られている。Cracco ら ${ }^{3)} や$ Desmedt ら ${ }^{4)}$ による臨床研究に执いてもこれとほぼ 一致した見解が得られつつある。

一方, 各成分の振幅は動物実験例が臨床例より も著しく高振幅な場合があり $5,8,13)$, これは SEP 


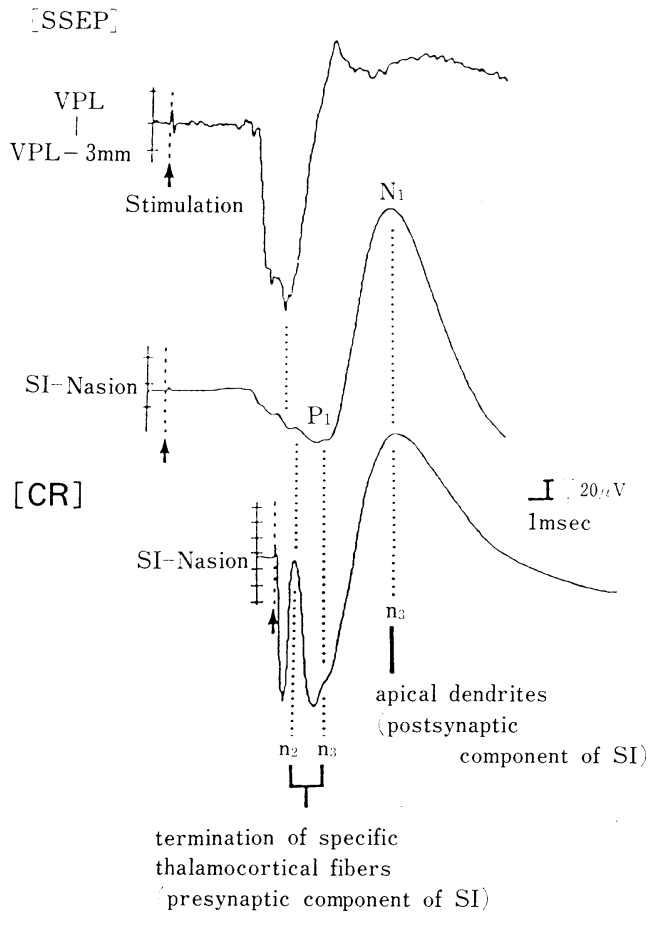

Fig. 8 Comparison of SSEP recorded from VPL and SI and CR recorded from SI

記録部位の違いや刺激強度の差によるものと思わ れる。本実験に拮いても運動閾值の 3 倍の刺激強 度を用いることにより皮質表面から $200 \mu \mathrm{V}$ 以上 の SEP 波形を記録しているが，各猫に执いて振 幅にかなりのばらつきを認めた。

VPL で記録した SSEP は多峰性陽性波であ り, VPL 通過後は速やかに陽性成分から陰性成 分への逆転を示し Goto $5^{6)}$ の報告とも一致して いた。本実験では電極間距離 $3 \mathrm{~mm}$ での記録で あり, VPL 独自の誘発電位とするには疑問の残 るところであるが，VPL に抮ける電位変化をほ ぼ正確に反映しているものと考光られた。

視床 VPL 刺激を行って SI で記録した CR は, 純粋に大脳皮質起源の電位変化を示している ものと考兄られ, 連続した小さな陰性波 $\mathrm{n}_{1}, \mathrm{n}_{2}$ が presynaptic component つまり求心性線維の スパイク発射と皮質深層の錐体細胞自体の興奮で あり, 高振幅の陰性波 $\mathrm{n}_{3}$ が postsynaptic component つまり尖端樹状突起のシナプス後電位起 源であると思われる10,12)。
本実験に招いて SSEP と CR の相関をみる と, ictal stage では SI で記録した CR の $\mathrm{n}_{3}$ と同部位で記録した SSEP の $\mathrm{N}_{1}$ が同様な変化 を示し, control study に拈ける皮質層分析の結 果とも一致して括り， $\mathrm{n}_{3}$ と $\mathrm{N}_{1}$ とは同一起源で あるものと推測される。Fig. 8 はこの $\mathrm{n}_{3}$ と $\mathrm{N}_{1}$ を同一潜時上飞配置し，VPL とSI で記録した SSEP と CR を比較したものである。この図か らSIで記録したSSEP に拁ける $\mathrm{P}_{1}$ の起源を 見ると, $\mathrm{P}_{1}$ の後半部は $\mathrm{n}_{1}, \mathrm{n}_{2}$ と同潜時で, 解 剖学的立場から同一の神経路によるものと思わ れ, thalamocortical projection 由来と思われた。 しかし $\mathrm{P}_{1}$ の前半部はさらに早い潜時を持って 扣り, VPL に起源が求められることが示唆され た。

\section{Interictal stage での SSEP と GR の変} 化に関して

高橋 ${ }^{13}$ は rat の皮質感覚領野に Pc 焦点を作 成した実験に扣いて, 高振幅棘波が規則的に出現 している時期では SEP 成分の振幅増大を示した としている。岩山ら ${ }^{8)}$ は, 猫の一側皮質感覚領野 に Pc 焦点を作成し, 同部で記録した SEP の変 化を報告している。それによると interictal stage に扣いて $\mathrm{P}_{1}$ に相当する成分の潜時の延長と振幅 の増大を認め, これは皮質 $\mathbb{I}, \mathbb{N}$ 層に和ける二ュ 一ロン活動の増加に関係していると述べている。 またこれに続く高振幅の陰性成分を認めて㧤り, この陰性成分が発作波炎のものではないかとして いる。本実験に和ける interictal stage での SSEP 扣よび CR では, stage I, II と同様に正常波形 が保たれて和り，はたして VPL 焦点部に执いて も二ューロン活動の増加や発作波の誘発が起こり 得るものかどらかについて, 明らかな現象を捉光 ることはできなかった。

\section{Ictal stage での SSEP と GR の変化に関}

\section{して}

岩山ら ${ }^{8)}$ の報告では, 持続性発作波の発現時に はSEP が認められず，発作時に和けるニューロ ンの持続性脱分極により知覚刺激化対して全く反 応しなくなったためと述べている。すた鏡焦点に おいても原焦点部と同様な持続性発作波を認める ictal stage ではSEP が消失したとしている9。 
本実験では, 原焦点部 VPL においても, また対 側 VPL に和いても，SEP は消失して扮らず振 幅の低下と持続時間の 延長を認め, 岩山らの interictal stage に打けるSEP 変化と類似してい た。この所見から見ると視床 Pc 焦点部周辺の VPL ニューロンに反応性が多少なりとも残存し ていた可能性も示唆され, 本実験に和ける ictal stage を本当の意味での generalized convulsion seizure と考光得るかどうか疑問の残るところで あり，今後の検討が必要である。SI で記録した SSEP に执いても ictal stage では両側とも大脳皮 質由来と考兄られる $\mathrm{N}_{1}$ の正常波形は消失してい たが，視床 VPL 由来と考学らるる $\mathrm{P}_{1}$ の前半部 は残存して拈り, ictal stage に㨟いても正中神経 刺激によるインパルスが視床の VPL ニューロン にまで到達していたのではないかと思われた。 Ictal stage 中どの伝導路を介してインパルスが 視床にまで到達し得るのかその詳細は不明である が, Iragui-Madoz らの猫 SEP に括ける component は，人とかなり異なったパターンを示し て扣り，猫では楔状核などの脳幹部ニューロンを 介さず直接または小脳経路から視床に到達する伝 導路の発達している可能性が推測された。

Ictal stage に SI で記録した CR では, 尖 端樹状突起のシナプス後電位起源と思われる $\mathrm{n}_{3}$ が消失または逆転する傾向を示していたのに対 し, 求心性線維のスパイク発射と皮質深層の錐体 細胞自体の興奮と思われる $\mathrm{n}_{1}, \mathrm{n}_{2}$ は明らかに認 められた。このことは VPL 刺激が直接 thalamocortical projection に括恀子求心性線維のスパ イク発射を促し，そのインパルスが大脳皮質深層 にまで到達していたのではないかと推察された。

稿を終えるにあたり, 御指導と御校閲を賜わりまし た松本圭蔵教授に深く感謝致します。

な招, 本論文の要旨は, 第25回日本定位脳手術研究 会 (1986年 9 月, 東京) と第16回日本脳波・筋電図学 会学術大会（1986年10月，筑波）にて発表した。

\section{文献}

1) Brooks, V.B., Rudomin, P., Slayman, C.L. (1961) Sensory activation of neurons in the cat cerebral cortex. J Neurophysiol 24, 286-301

2) Burchiel, K.J., Myers, R.R., Bickford, R.G.
(1976) Visual and auditory evoked responses during penicillin-induced generalized spike-and -wave activity in cats. Epilepsia 17, 293-311

3) Cracco, R.Q., Cracco, J.B. (1976) Somatosensory evoked potentials in man: far field potentials. Electroencephalogr Clin Neurophysiol 41, $460-466$

4) Desmedt, J.E., Cheron, G. (1980) Central somatosensory conduction in man: Neuronal generators and interpeak latencies of the far-field components from neck and right or left scalp and earlobes. Electroencephalogr Clin Neurophysiol 50, 382-403

5) Dong, W.K., Harkins, S.W., Ashleman, B.(1982) Origins of cat somatosensory far-field and early near-field evoked potentials. Electroencephalogr Clin Neurophysiol 53, 143-164

6) Goto, A., Kosaka, K., Kubota, K., Nakamura, R., Narabayashi, H. (1968) Thalamic potentials from muscle afferents in the human. Arch Neurol 19, 302-309

7) Iragui-Madoz, W.J., Wiederholt, W.C. (1977) Far field somatosensory evoked potentials in the cats. Electroencephalogr Clin Neurophysiol 43, 646-657

8）岩山 馨, 森 和夫, 山城勝美, 馬場啓至 (1978) 発作波と体性知覚誘発電位 (第 1 報) 一ネコの皮 質知覚領焦点部活打る变動一, 脳神経 $\mathbf{3 0}$, 1001-1008

9）岩山 馨, 森 和夫, 山城勝美, 上之郷真木雄 （1979）発作波と体性知覚誘発 電位（第 2 報）ネコの皮質知覚領鏡焦点部における変動一. 脳神 経 31，501-507

10）松本圭蔵, 大本堯史, 難波真平, 宮本俊彦(1971) 視床核刺激と皮質誘発反応一とくにヒトと動物の 差異について一，脳神経 23，41-51

11) Mirsky, A.F., Bloch, S., Tecce, J.J., Lessell, S., Marcus, E. (1973) Visual evoked potentials during experimentally induced spike-waveactivity in monkeys. Electroencephalogr Clin Neurophysiol 35, 25-37

12）岡宏 (1979) 大脳皮質誘発電位の成因. 神経 進歩 23, 234-248

13) 高橋 宏 (1980) 焦点性棘波の感覚性誘発電位に 対する影響一ネズミてんかんモデルに䄧ける検討 一. 脳神経 32, 1207-1213

14）鶴 紀子, 二宮英彰, 福岡 寛, 池田睴親(1980) 猫・扁桃核刺激による Kindling の聴覚ならびに 視覚誘発電位に及ぼす影響. 脳神経 32, 191-198 


\section{Summary}

\section{Experimental Studies on Development and Propagation of Epileptic Spikes in Penicillin-induced Thalamic Focus Model \\ Part 2. Effects on Somatosensory Evoked Potentials and Cortical Response}

Tetsuro Soga

The present study was especially undertaken to investigate the effects of penicillin (Pc) induced thalamic focus on short latency somatosensory evoked potentials (SSEP) by the median nerve stimulation and cortical response (CR) by stimulation of the ventral posterolateral nucleus (VPL) of the thalamus. Details of the model should be refered to part 1. Changes of EEG recorded from VPL after the application of Pc were classified as Stage I (phage of sporadic spike discharges), II (frequent spikes and polyspikes) and $\mathbb{I I}$ (volley of ictal discharges). SSEP normally consisted of a large positive (P) wave (the maximal peak latency: $7.1 \pm 0.6 \mathrm{msec}$ ) in VPL and $P_{1}(9.4 \pm 0.9 \mathrm{msec}$ ) and $\mathrm{N}_{1}(14.1 \pm 0.8 \mathrm{msec})$ in the primary somatosensory cortex (SI).CR normally consisted of two small negative waves $\left(n_{1}: 1.3 \pm 0.4 \mathrm{msec}, \mathrm{n}_{2}: 3.2 \pm 0.4 \mathrm{msec}\right)$, followed by a large negative wave $\left(\mathrm{n}_{3}: 6.8 \pm 0.8 \mathrm{msec}\right)$. The components of SSEP and CR at stage I and II revealed no remarkable changes. On the other hand, the latency of $P_{1}$ had prolonged and $\mathrm{N}_{1}$ disappeared at ictal stage of stage $\mathbb{I}$. The latency and amplitude of $\mathrm{n}_{1}$ and $\mathrm{n}_{2}$ revealed no remarkable changes but $\mathrm{n}_{3}$ was disappeared or reversed to positive at ictal stage of stage $\mathbb{I I}$. The amplitude of $\mathrm{P}$-wave decreased but not disappeared at ictal stage. In interictal stage, SSEP and CR returned to normal patterns. These findings of SSEP and CR were similarly obtained either in the hemisphere of Pc injection or non-injection sides. It is suggested that the finding of disappearance of $\mathrm{N}_{1}$ may be due to a block of the thalamocortical projection.

J. Jpn. Epil. Soc. 1989; 7: 179-188

(received: February, 21, 1989, revised: July, 11, 1989, accepted: July, 13, 1989) 